\section{Books to Read Before You Graduate High School}

Richard J. Barohn MD, Joshua Freeman MD, John Kissel MD, Marc Wallis, Jonathan Katz MD, Todd

Levine MD, Dave Saperstein MD, Omar Jawdat MD, Joel Barohn MS, Erik R Ensrud MD, Kenneth

Gorson MD, Laura Herbelin, Russel Swerdlow MD, Jeff Burns MD, Gretchen Ayer, Karen Easton, Carlayne Jackson MD, Richard Dubinsky MD, Sonya

Fabricius, Aziz Shaibani MD, Tahseen Mozafar

MD, Gil Wolfe, Walter Anderson, Ted Burns MD, Jeffery Statland MD, Mamatha Pasnoor MD, Mazen

Dimachkie MD, Anthony Amato MD

In 2016 when two close friends and one of my cousins all had children ready to be Bar or Bat mitzvahed, I had to think of gifts. Bar Mitzvah is for boys and Bat Mitzvah is for girls. Rather than a typical gift (check, cash) I decided to come up with a list of books they should consider reading before they graduated high school, and I was also planning to give them a book bag containing most or all of them on the list. The original goal was to come up with 13 books to correspond to the age 13 at which Jewish boys at least go through the Bar Mitzvah ceremony. Girls go through the rite of passage at age 12 or 13, depending on their tradition. I began to email many of my friends to try to get some consensus on such a list. That was not as easy as I thoughtmany different views on this! My starting point was that we would not have a book on the list that they probably would've been assigned to read as required reading during junior high and high school. This also was not as easy as I thought as all my friends had graduated high school either 20 to 40 years ago and what we were required to read then has changed, or so it seems. I had my son Joel, as the closest to high school, weigh in as well to give us a current reality base. So, over a period of weeks and many email exchanges we came up with "the list of books you should read before you graduate high school." I was able to get the first thirteen in paperback for each Bar or Bat Mitzvah and I can say that each teenager that we gave the book bag to thought it was a great and unique gift and so did their parents. The book bag included both lists of 13 books, so they had the list of the next 13 to try to find as well. How many of these they read, I don't know. But one of the dads would tell me he would see all the books laying around in different places and it looked like they were reading them...maybe.

Flush with this success, the original group of book list contributors decided to send in a short letter to the editor of the New York Times with a few lines of introduction and then the list of the 13 books. We saw it was received by the NYT but we never got a response. So it goes.

In 2019 another set of teenagers were up for Bar and Bat Mitzvah-same parents (prolific parents). I took out the original lists we did and they just did not look right even after all of the back and forth we went through at the time. I thought some of the books were too advanced for our current 13-year olds, and some may have in fact been on the edge of being a bit too explicit sexually. I was worried perhaps we were crossing the line in the eyes of some of the parents. One that comes to mind is Phillip Roth's Goodbye Columbus. Should we really be telling kids to read this in high school and would their parents approve? Or is this more of a book for college reading? And Sophie's Choice by William Styron was in the second 13 to read list. Again, should this have been a college book?

So, in May 2019 I resent the list to my colleagues and said I wanted to revise the list. Also, when we put together the first 13 books, they were mainly male authors. We did ultimately include several female authors (Eudora Welty, Virginia Wolfe, Flannery O’Connor, Sandra Cisneros) but we thought we should add more female authors. We also had very little diversity. What we ended up developing was a list of 20 male authors for fiction and 20 female authors for fiction: total of 40 fiction books. Then we also added 13 nonfiction books; 5 poetry books and a Shakespeare play. Then there was a lot of discussion on including foreign language (non-English) authors in translation- should we or shouldn't we? In the end I think we did limit the lists to authors writing in English. One exception is the nonfiction list in that we kept "The Way of Life" according to Laotzu, translated by Witter Bynner, an amazing translation of an essential book that is accessible to teenagers. All of these were supposed to be in addition to whatever books they were required to read in high school and we renamed the list as: Books to read before finishing high school from 13 to 17: The Bar/ Bat Mitzvah/ Sweet 16/ Quinceanera/ Confirmation reading list. Since the number of books had expanded, I gave each Bar/Bat Mitzvah a book bag of about 6 books as well as the list of all the other books.

The following is the letter to the editor to the NYT we sent on October $27^{\text {th }}, 2016$ and the two lists of 13 (Table 1,2). It was in response to an article in the NYT on October $25^{\text {th }}$, 2016 that was titled "12 Books to Read in your 20s." 
Letter to the Editor:

RE: 12 Books to Read in your 20s, appearing on 111.nytimes.com on October $25^{\text {th }}, 2016$

Attachments: Letter to the Editor, Book list participants.

Must read book lists seem to be growing in popularity. I am frequently invited to Bar/ Bat Mitzvahs, and instead of the usual gifts, I came up with an idea of presenting each young teenager with the 13 books they should read before high school graduation. They generated many suggestions with some cautions. We stayed away from children's books and those that are commonly read in college courses. We aimed for diversity and inclusion and chose the books we believed sill had "legs," providing a lasting impression in our adult years. A list is attached.

Richard J. Barohn MD

Chairman

Gertrude and Dewey Ziegler Professor of Neurology

University of Distinguished Professor

Vice Chancellor of Research

President, Research Institute

Director, Heartland Initiate for Clinical and

Translational Research

University of Kansas Medical Center

List of Participants who created the 13 Books to Read Before Graduating High School and the next 13 Books to Read before Graduating High School:

Joshua Freeman MD, John Kissel MD, Marc Wallis, Jonathan Katz MD, Todd Levine MD, Dave Saperstein MD, Omar Jawdat MD, Joel Barohn, Erik R Ensrud MD, Kenneth Gorson MD, Laura Herbelin, Russel Swerdlow MD, Jeff Burns MD, Gretchen Ayer, Karen Easton, Carlayne Jackson MD, Richard Dubinsky MD, Sonya Fabricius
Table 1. 13 Sept 2016 Bar, Bat \& B’nai Mitzvah Book List

13 Books to ReAD

Before Graduating High School That Are Not on the Required Reading Lists

(To be read in recommended order between ages 1318)

According to Rick Barohn and Friends

1. Siddhartha

Hermann Hesse

2. The World's Religions

Houston Smith

3. Franny and Zooey

J.D. Salinger

4. Cat's Cradle

Kurt Vonnegut

5. The House on Mango Street

Sandra Cisneros

6. The Caine Mutiny Herman Wouk

7. Goodbye, Columbus: And Five Short Stories Philip Roth

8. A Good Man is Hard to Find: And Other Stories Flannery O'Connor

9. Thirteen Stories Eudora Welty

10. A Room of One's Own Virginia Woolf

11. The Great Gatsby F. Scott Fitzgerald

12. The Way of Life, According to Laotzu Witter Bynner

13. A Portrait of the Artist as a Young Man James Joyce 
Table 2. 13 Sept 2016 Bar, Bat \& B’nai Mitzvah Book List

The Next 13 Books to ReAd

Before Graduating High School That Are Not on the Required Reading Lists

(To be read in recommended order)

According to Rick Barohn and Friends

1. A Separate Peace

John Knowles

2. The World According to Garp

John Irving

3. Sophie’s Choice

William Styron

4. The Maltese Falcon

Dashiell Hammett

5. The Big Sleep

Raymond Chandler

6. The Bell Jar

Sylvia Plath

7. Raise High the Roof Beam, Carpenters and Seymour: An Introduction

J. D. Salinger

8. Walden Two

B. F. Skinner

9. Dubliners

James Joyce

10. The Story of Philosophy: The Lives and Opinions of the World's Greatest Philosophers

Will Durant

11. The Hero with A Thousand Faces

Joseph Campbell

12. On the Road

Jack Kerouac

13. The Sun Also Rises

Ernest Hemingway

When we revised the list in May 2019 I enlisted additional input. All the individuals above participated and we added input from the following participants:

Aziz Shaibani MD, Tahseen Mozafar MD, Gil Wolfe, Walter Anderson, Ted Burns MD, Jeffery Statland MD, Mamatha Pasnoor MD, Mazen Dimachkie MD, Anthony Amato MD.

The following is the revised list:
Table 3. Fiction Books to Read Before Finishing High School Age 13-17: The Bar/ Bat Mitzvah/ Sweet 16/ Quinceanera/Confirmation Reading List.

\section{Female Authors}

1. Muriel Spark- The Prime of Miss Jean Brodie

2. Virginia Woolf- Mrs. Dalloway

3. Sandy Cisneros- The House on Mango Street

4. Eudora Welty- Thirteen Stories

5. Flannery O' Connor- A Good Man is Hard to Find

6. Charlotte Bronte- Wuthering Heights

7. Emily Bronte- Jane Eyre

8. Jane Austen- Sense and Sensibility

9. George Eliot- The Mill on the Floss

10. JK Rowling- All Harry Potter if not read by age 13

11. Anna Sewell- Black Beauty

12. Daphne Du Maurier- Rebecca

13. Ursula K. Le Guin- The Left Hand of Darkness

14. Laura Esquivel- Like Water for Chocolate

15. Carson McCullers- The Member of the Wedding

16. Laura Ingalls Wilder- Little House on the Prairie series

17. Sylvia Plath- The Bell Jar

18. Toni Morrison- The Bluest Eye

19. Betty Smith-A Tree Grows in Brooklyn

20. Louisa May Alcott- Little Women

Table 4. Fiction Books to Read Before Finishing High School Age 13-17: The Bar/ Bat Mitzvah/ Sweet 16/ Quinceanera/Confirmation Reading List.

\section{Male Authors}

1. CS Forester-Captain Horatio Hornblower trilogy

2. Charles Dickens- Pickwick Papers (assuming Great Expectations was required)

3. Mark Twain-Connecticut Yankee in King Arthur's Court (assuming Tom Sawyer and Huck Finn were required)

4. James Baldwin- Go Tell it On the Mountain

5. Kurt Vonnegut- Cat's Cradle and Slaughterhouse Five

6. J.D. Salinger- Franny and Zoey and The Catcher in the Rye

7. J.R.R. Tolkien- The Hobbit

8. Jack Kerouac- On the Road

9. Daniel Quinn- Ishmael

10. Aldous Huxley- Brave New World 
11. George Orwell- 1984

12. Ernest Hemingway- The Short Stories of Ernest Hemingway or In Our Time (short stories)

13. Hermann Hesse- Siddhartha

14. Franz Kafka- The Metamorphosis

15. John Knowles- A Separate Peace

16. John Steinbeck- Of Mice and Men

17. RL Stevenson- Treasure Island

18. Ray Bradbury- Fahrenheit 451

19. AC Doyle- Begin reading all Holmes...start w/ A Study in Scarlet and The Red Headed League

20. Dashiel Hamlett- The Maltese Falcon

\section{Table 5. Nonfiction: The Bar 13}

1. Anne Frank- The Diary of A Young Girl

2. Hellen Keller- The Story of My Life

3. Virginia Woolf- A Room of One's Own

4. Houston Smith- The World's Religions

5. The Way of Life, According to Laotzu translated by Witter Bynner

6. Will Durant- Story of Philosophy

7. Henry David Thoreau- Walden

8. James Baldwin- Notes of a Native Son

9. Maya Angelou- I Know Why the Caged Bird Sings

10. Malcolm X-The Autobiography of Malcolm X

11. Elie Wiesel- Night

12. John F. Kennedy- Profiles in Courage

13. Barack Obama- Dreams from My Father: A Story of Race and Inheritance

\section{Table 6. Poetry}

1. T.S. Eliot- The Love Song of J. Alfred Prufrock

2. Emily Dickinson- Start reading all poems

3. Maya Angelou- On the Pulse of the Morning (read at Bill Clinton's inauguration)

4. John Keats- Ode to a Nightingale; Ode on a Grecian Urn

5. Robert Frost-A Boy's Will

\section{Table 7. Plays}

1. Shakespeare-Henry IV Part 1 (presuming Julius Caesar, Romeo and Juliet and Hamlet were required reading.)
After creating the above lists, I began making other lists:

$$
\begin{array}{cl}
\circ & \text { Books you need to read between the ages } \\
8 \text { to } 12 & \\
\circ & \text { Books you need to read before graduating } \\
\text { college (approximately } 18 \text { to } 22) \\
\circ & \text { Books you need to read before } 30 \\
\circ & \text { Books you need to read before } 40 \\
\circ & \text { Books you need to read before } 50 \\
\circ & \text { Books you need to read before } 60 \\
\circ & \text { Books you need to read before } 70 \\
\circ & \text { Books you need to read before } 80 \\
\circ & \text { Books you need to read before } 90
\end{array}
$$

The largest list is in books to read before college and before 30 . Here is when I began to insert all of the nonEnglish writing authors that had come up in the teenage list. With each successive decade, I have fewer and fewer books in each category. The books to read by 90 is a bit short!

But over the last decade there have been a number of books called "books to read before you die" or some similar titles. Two of my favorites are: 1001 Books You Must Read Before You Die, written by more than 100 international critics, General Editor Peter Boxall, Universe Publishing, New York, NY 2015; and 1000 Books to Read Before you Die, A Life-Changing List by James Mustich, Workman Publishing Co, New York, NY, 2018. But I thought I would hone down a bit by going decade by decade and I did not refer to either of these published books as I made my lists.

In future "what's on your mind" columns I will provide some of these lists.

Rick and fellow list creators 